\title{
Heavy Metals in Agricultural Soils from a Typical Mining City in China: Spatial Distribution, Source Apportionment, and Health Risk Assessment
}

\author{
Jiaxi Tang ${ }^{1}$, Miaomiao He ${ }^{2}$, Qing Luo ${ }^{3 *}$, Muhammad Adeel ${ }^{4}$, Feng Jiao ${ }^{1}$ \\ ${ }^{1}$ College of Environmental Science and Engineering, Liaoning Technical University, Fuxin, China \\ ${ }^{2}$ College of Civil Engineering, Liaoning Technical University, Fuxin, China \\ ${ }^{3}$ Key Laboratory of Regional Environment and Eco-Remediation of Ministry of Education, College of Environment, \\ Shenyang University, Shenyang, China \\ ${ }^{4}$ Beijing Key Laboratory of Farmland Soil Pollution Prevention and Remediation, College of Resources and Environ- \\ mental Sciences, China Agricultural University, Beijing, China
}

Received: 11 February 2019

Accepted: 14 April 2019

\begin{abstract}
This study investigated the spatial distribution, sources, and health risks of heavy metals (As, $\mathrm{Cd}, \mathrm{Cr}$, $\mathrm{Cu}, \mathrm{Hg}, \mathrm{Ni}, \mathrm{Pb}$, and $\mathrm{Zn}$ ) in agricultural topsoils in Fuxin, China. One-hundred and thirty-eight topsoil samples were collected from Fuxin in August 2017. Except for $\mathrm{Cu}, \mathrm{Hg}$, and $\mathrm{Pb}$, the mean concentrations of other heavy metals surpassed their respective background values. The mean concentration of Cd was nine times that of the background value. For the majority of heavy metals, contents in the Haizhou and Xihe areas and south of Fumeng County were significantly higher than those of other areas. The results of the geoaccumulation and potential ecological risk indexes revealed that $\mathrm{Cd}$ demonstrated moderate contamination. The Haizhou and Xihe areas were considerable risk areas, whereas heavy metals in other areas posed low risks. Results of the health risk assessment revealed that the non-carcinogenic risks caused by heavy metals were small-beer. The carcinogenic risks caused by $\mathrm{Ni}, \mathrm{Cr}$, and As surpassed acceptable levels. Based on the results of source apportionment, which is based on positive matrix factorization, agricultural sources contributed to half of the concentration of heavy metals; industrial and traffic sources contributed $32.12 \%$ and $14.97 \%$, respectively.
\end{abstract}

Keywords: heavy metal, spatial distribution, source apportionment, health risk assessment, positive matrix factorization

*e-mail: luoqingyt@126.com 


\section{Introduction}

Heavy metal contamination in soil has become a serious environmental problem in many countries [1-4]. In China, soil pollution by heavy metals caused by human activities, such as industrial discharge, fertilization, mining, and transportation, is severe due to the expanding urbanization and industrialization [57]. Heavy metals in soil are non-degradable, which can affect the properties of soil and lead to the destruction of soil ecological function, penetrate the food chain, and jeopardize human health [8-10]. Heavy metal pollution in agricultural soil is directly related to the issue of food security, which has attracted increasing concern.

In the literature, many studies on heavy metal pollution in urban and agricultural soil have been conducted in China and abroad [6, 10-16]. For example, the average concentrations of $\mathrm{Cu}, \mathrm{Zn}$, $\mathrm{Cr}$, and $\mathrm{Cd}$ were detected at 274, 1,827, 1,085, and $2.50 \mathrm{mg} \mathrm{kg}^{-1}$, respectively, in the Faridabad industrial area of India [15]. Concentrations of eight heavy metals in urban topsoil from Shaanxi, China were found to be slightly above their respective background values - especially $\mathrm{Cd}$ and $\mathrm{Hg}$ [6]. The concentrations of six heavy metals in soils, which were collected from an electronic manufacturing region, were highest in the commercial area; the carcinogenic risks (CRs) of As and $\mathrm{Cr}$ to humans were above other heavy metals [16]. The concentrations of heavy metals were distinctly different across land use types, and soil metal concentrations in industrial lands demonstrated relatively higher levels than those of farmlands [7]. The concentrations of $\mathrm{Cu}$, $\mathrm{Zn}, \mathrm{Pb}$, and $\mathrm{Cd}$ in paddy soil were significantly higher than the maximum allowable concentrations in Chinese agricultural soil [17]. In the agricultural surface soil in the peri-urban areas in southeast China, the contents of heavy metals in upland were higher than those of paddy soil and tea gardens; high concentrations were mostly observed along roadsides and near mining areas [18]. The pollution in agricultural soil in China is widespread due to mining, industrial, and agricultural activities, according to the results of a national soil survey [19].

Fuxin city is one of the early coal energy bases in China, which is an important energy industrial base, and a pilot city of circular economy and resource exhaustion transformation. Over the past few decades, Fuxin has produced more than 500 million tons of coal and generated more than 150 billion kilowatts of electricity, making tremendous contributions to the national economic construction. A considerable amount of coal gangue and fly ash have been discharged in coal mining and power production for many years, and more than 200 coal gangue hills and dump sites of varying sizes have been formed in and around the city. Such a large amount of coal gangue and fly ash has caused serious environmental problems, such as soot and dust and groundwater and soil pollution in urban and rural areas of Fuxin city. The heavy metal pollution in soil is becoming a severe problem because of industrial activities, which can harm public health. Therefore, identifying the source of heavy metals in soil, analyzing the spatial distribution, and assessing the health risks in this area are necessary to provide a basis for controlling contamination levels and improving soil quality. However, related research on the possible health risk caused by metal contamination in agricultural soil in a typical mining city (Fuxin) remains reported. The main objectives of the present study were to (1) estimate the concentrations of heavy metals (As, $\mathrm{Cd}, \mathrm{Cr}, \mathrm{Cu}, \mathrm{Hg}$, $\mathrm{Ni}, \mathrm{Pb}$, and $\mathrm{Zn}$ ) in agricultural soil and describe their spatial distribution, (2) analyze the potential sources of heavy metals, and (3) evaluate contamination levels, potential ecological risk, and health risk of heavy metals in agricultural soils.

\section{Materials and Methods}

\section{Study Area}

This research was implemented in Fuxin city, which is located northwest of Liaoning Province in northeast China, with an aggregate area of $10,445 \mathrm{~km}^{2}$ and total population of more than 1.8 million. The city has five jurisdictions and two county-level cities administered by 65 townships. Fuxin is located in the north temperate semi-arid continental monsoon climate zone. The annual mean temperature is $7.8^{\circ} \mathrm{C}$, and the annual average rainfall is $489 \mathrm{~mm}$. The agricultural land accounts for $74.65 \%$ of the total area. The Fumeng and Zhangwu county-level cities are the major food- and oil-producing bases in Liaoning province, with the main production of peanuts and corn. The main sources of pollution are mining and chemical-related industries, fertilizers, vehicles, and other anthropogenic activities.

\section{Soil Sampling and Chemical Analysis}

Soil samples were collected in August 2017. 138 agricultural topsoil samples $(0-10 \mathrm{~cm})$ were collected as a mixture of five subsamples taken from the same depth from 65 townships. Fig. 1 depicts the sampling points. After removing stones, organic debris, and other dopants, soils were air dried, crushed, homogenized, and sieved through a $0.149-\mathrm{mm}$ nylon mesh, then stored for further analysis. Eight heavy metals, namely As, $\mathrm{Cd}, \mathrm{Cr}, \mathrm{Cu}, \mathrm{Hg}, \mathrm{Ni}, \mathrm{Pb}$, and $\mathrm{Zn}$, were evaluated. Two $0.5 \mathrm{~g}$ soils were digested with different mixtures of acids on a hot plate. One of the aliquots was for the detection of $\mathrm{Cd}, \mathrm{Cr}, \mathrm{Cu}, \mathrm{Ni}, \mathrm{Pb}$, and $\mathrm{Zn}$, and digested with $\mathrm{HCl}, \mathrm{HNO}_{3}, \mathrm{HF}$ and $\mathrm{HClO}_{4}$ (5:5 and 5:3 in volume). The other one was for the detection of $\mathrm{As}$ and $\mathrm{Hg}$ and digested with $\mathrm{HCl}$ and $\mathrm{HNO}_{3}$ (1:3 in volume). The method and procedure of the treatment are consistent with previous studies [14]. The concentrations of heavy metals $(\mathrm{Cd}, \mathrm{Cr}, \mathrm{Cu}, \mathrm{Ni}, \mathrm{Pb}$, and $\mathrm{Zn})$ were analyzed by inductively coupled plasma mass spectrometry (ICP-MS, PerkinElmer NexION 350X, 


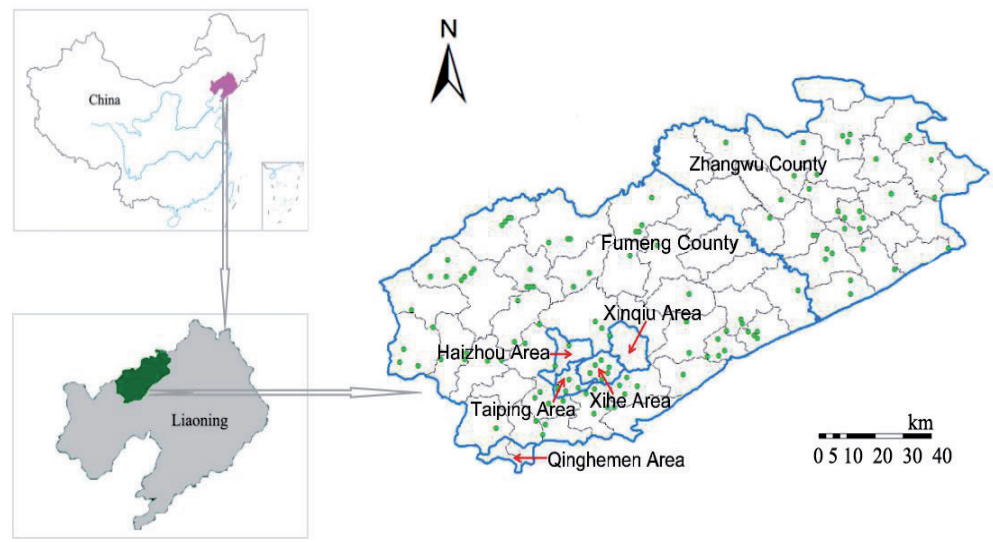

Fig. 1. Locations of the sampling points.

USA), and As and $\mathrm{Hg}$ were measured using atomic fluorescence spectrometry (PF7-2, Beijing Purkinje General Instrument Ltd., Beijing, China). Quality assurance and quality control (QA/QC) were conducted by reagent blanks, duplicates, and standard reference material (GBW07401, Center of National Standard Reference Material of China). The recovery rates ranged from $92.86 \%$ to $105.21 \%$. Three duplicates were used for all analyses, and relative standard deviations of duplicate samples were less than $5.0 \%$.

\section{Assessment Methods for Heavy Metals}

\section{Pollution Assessment}

To evaluate the heavy metal pollution levels and ecological risks in soil, the geoaccumulation index $\left(\mathrm{I}_{\text {geo }}\right)$ and potential ecological risk index (RI) were used. $\mathrm{I}_{\text {geo }}$ is the most mainstream index used to assess the pollution degree of heavy metals in soil [20-21]. RI was applied to quantify the potential ecological risk according to the toxicity and content of a given contaminant [22]. $\mathrm{I}_{\text {geo }}$ was calculated as follows [23]:

$$
I_{\text {geo }}=\log _{2}\left(\mathrm{C}_{\mathrm{n}} / 1.5 \mathrm{~B}_{\mathrm{n}}\right)
$$

...where $\mathrm{C}_{\mathrm{n}}$ is the examined concentration of metal $\mathrm{n}$, and $\mathrm{B}_{\mathrm{n}}$ represents the background value of metal $\mathrm{n}$. Table 1 lists the classification standards.

RI was estimated as follows [14]:

$$
\begin{gathered}
R I=\sum_{\mathrm{i}=1}^{\mathrm{n}} \mathrm{E}_{\mathrm{r}}^{\mathrm{i}} \\
E_{r}^{i}=\mathrm{T}_{\mathrm{r}}^{\mathrm{i}} \times \mathrm{C}_{\mathrm{f}}^{\mathrm{i}} \\
C_{f}^{i}=\mathrm{C}_{0-1}^{\mathrm{i}} / \mathrm{C}_{\mathrm{n}}^{\mathrm{i}}
\end{gathered}
$$

Table 1. Classification standards of three indexes.

\begin{tabular}{|c|c|c|}
\hline \multirow{4}{*}{ Index } & Category & Description \\
\hline \multirow{4}{*}{ Geo-accumulation index $\left(I_{g e o}\right)$} & $I_{g e o} \leq 0$ & Practically uncontaminated \\
\cline { 2 - 3 } & $0<I_{g e o} \leq 1$ & Uncontaminated to moderately contaminated \\
\cline { 2 - 3 } & $1<I_{g e o} \leq 2$ & Moderately contaminated \\
\cline { 2 - 3 } & $2<I_{g e o} \leq 3$ & Moderately to heavily contaminated \\
\cline { 2 - 3 } & $3<I_{g e o} \leq 4$ & Heavily contaminated \\
\cline { 2 - 3 } & $4<I_{g e o} \leq 5$ & Heavily to extremely contaminated \\
\hline \multirow{3}{*}{ Ecological risk $(R I)$} & $5<I_{g e o}$ & Extremely contaminated \\
\cline { 2 - 3 } & $2 I \leq 150 ; E_{r}{ }^{i} \leq 40$ & Low risk \\
\cline { 2 - 3 } & $300<\mathrm{RI} \leq 600 ; 80<\mathrm{E}_{\mathrm{r}}^{\mathrm{i}} \leq 160$ & Moderate risk \\
\cline { 2 - 3 } & $600<\mathrm{RI} ; 160<\mathrm{E}_{\mathrm{r}}^{\mathrm{i}} \leq 320$ & Considerable risk \\
\cline { 2 - 3 } & $320<\mathrm{E}_{\mathrm{r}}^{\mathrm{i}}$ & High risk \\
\cline { 2 - 3 } & & Extreme risk \\
\hline
\end{tabular}


Table 2. Values of these parameters in exposure assessment.

\begin{tabular}{|c|c|c|c|}
\hline & Unit & Children & Adults \\
\hline IngR & mg day ${ }^{-1}$ & 200 & 100 \\
\hline $\mathrm{EF}$ & day year ${ }^{-1}$ & 350 & 350 \\
\hline ED & year & 6 & 24 \\
\hline InhR & $\mathrm{m}^{3}$ day $^{-1}$ & 7.5 & 20 \\
\hline PEF & $\mathrm{m}^{3} \mathrm{~kg}^{-1}$ & $1.36 \times 10^{9}$ & $1.36 \times 10^{9}$ \\
\hline SA & $\mathrm{cm}^{2}$ & 2800 & 5700 \\
\hline $\mathrm{AF}$ & $\mathrm{mg} \mathrm{cm}-2$ & 0.2 & 0.07 \\
\hline \multirow[t]{2}{*}{ ABS } & \multirow[t]{2}{*}{ Unitless } & $\begin{array}{c}0.001 \\
\text { (non-carcinogenic) }\end{array}$ & $\begin{array}{c}0.001 \\
\text { (non-carcinogenic) }\end{array}$ \\
\hline & & 0.01(carcinogenic) & 0.01(carcinogenic) \\
\hline BW & $\mathrm{kg}$ & 15 & 70 \\
\hline \multirow{2}{*}{ AT } & \multirow{2}{*}{ day } & $\begin{array}{c}2190 \\
\text { (non-carcinogenic) }\end{array}$ & $\begin{array}{c}8760 \\
\text { (non-carcinogenic) }\end{array}$ \\
\hline & & $\begin{array}{c}25550 \\
\text { (carcinogenic) }\end{array}$ & $\begin{array}{c}25550 \\
\text { (carcinogenic) }\end{array}$ \\
\hline
\end{tabular}

..where $E_{r}^{i}$ represents the potential ecological risk factor for a single element, $\mathrm{T}_{\mathrm{r}}^{\mathrm{i}}$ represents the toxicity coefficients for heavy metal i, $C_{f}^{i}$ represents the pollution factor, $\mathrm{C}_{0-1}^{\mathrm{i}}$ represents the mean concentration of heavy metal $\mathrm{i}$, and $\mathrm{C}_{\mathrm{n}}{ }^{\mathrm{i}}$ represents the background reference value of heavy metal i. According to previous references, the toxicity coefficients $\left(\mathrm{T}_{\mathrm{r}}^{\mathrm{i}}\right)$ of $\mathrm{As}, \mathrm{Cd}, \mathrm{Cr}, \mathrm{Cu}, \mathrm{Hg}$, $\mathrm{Ni}, \mathrm{Pb}$, and $\mathrm{Zn}$ used were $10,5,2,5,40,5,5$, and 5, respectively [6].

\section{Health Risk Assessment}

To describe the probability of non-carcinogenic and CRs of heavy metals to humans, health risk was assessed. In this study, adults and children were selected as the exposed people, where ingestion, dermal contact, and inhalation were selected as exposure pathways. The average daily intake $(A D I)$ of each heavy metal was estimated by the following equations [24]:

$$
A D I_{\text {ing }}=C \times \frac{\mathrm{IngR} \times \mathrm{EF} \times \mathrm{ED}}{\mathrm{BW} \times \mathrm{AT}} \times 10^{-6}
$$

$$
\begin{gathered}
A D I_{\text {derm }}=C \times \frac{\mathrm{SA} \times \mathrm{AF} \times \mathrm{ABS} \times \mathrm{EF} \times \mathrm{ED}}{\mathrm{BW} \times \mathrm{AT}} \times 10^{-6} \\
A D I_{i n h}=C \times \frac{\mathrm{InhR} \times \mathrm{EF} \times \mathrm{ED}}{\mathrm{PEF} \times \mathrm{BW} \times \mathrm{AT}}
\end{gathered}
$$

...where $A D I_{i n g}, A D I_{\text {derm }}$, and $A D I_{i n h}(\mathrm{mg} / \mathrm{kg} /$ day) are the $A D I$ s via ingestion, dermal contact, and inhalation, respectively; $C$ is the concentration of heavy metal in soil ( $\mathrm{mg} / \mathrm{kg})$; IngR is the ingestion rate of soil ( $\mathrm{mg} / \mathrm{day})$; $\mathrm{EF}$ is the exposure frequency (day/year); ED refers to exposure duration (year); BW pertains to body weight $(\mathrm{kg})$; AT is the average time (day); InhR is the inhalation rate of soil $\left(\mathrm{m}^{3} / \mathrm{day}\right)$; PEF is the particle emission factor $\left(\mathrm{m}^{3} / \mathrm{kg}\right)$; SA is the surface area of the skin in contact with soil $\left(\mathrm{cm}^{2}\right)$; AF is the relative skin adherence factor $\left(\mathrm{mg} / \mathrm{cm}^{2}\right)$ and ABS is the dermal absorption fraction of heavy metal (unitless). The values of these parameters were referenced from a previous study [25] and are shown in Table 2.

The non-CR (HQ) was assessed by the following equation [26]:

$$
\begin{array}{r}
\mathrm{HQ}_{i}=\frac{A D I_{i}}{R f D_{i}} \\
\mathrm{HI}=\sum \mathrm{HQ}_{i}
\end{array}
$$

...where $R f D$ is corresponding reference dose (mg/kg/day) and $i$ stands for exposure pathways. HI is the non-CR caused by all exposure pathways. If HI is higher than 1, then it indicates that the heavy metal poses non-CRs to humans. On the contrary, if HI is lower than 1, then the non-CRs are small-beer. The values of $R f D$ were referenced from a previous study [27], as shown in Table 3.

CR was calculated as follows [28]:

$$
\begin{aligned}
\mathrm{CR}_{\mathrm{i}} & =A D I_{i} \times \mathrm{SF} \\
\mathrm{CR} & =\sum \mathrm{CR}_{i}
\end{aligned}
$$

... where SF is the carcinogenic slope factor ( $\mathrm{mg} / \mathrm{kg} /$ day) and $i$ stands for exposure pathways. If CR is lower than $1 \times 10^{-6}$, then it indicates negligible health hazards. If $1 \times 10^{-6} \leq \mathrm{CR} \leq 1 \times 10^{-4}$, then it indicates that the CR is acceptable or tolerable. If CR is higher than $1 \times 10^{-4}$,

Table 3. Values of RfD and SF of heavy metal.

\begin{tabular}{|c|c|c|c|c|c|c|c|c|c|}
\hline & Unit & $\mathrm{As}$ & $\mathrm{Cd}$ & $\mathrm{Cr}$ & $\mathrm{Cu}$ & $\mathrm{Hg}$ & $\mathrm{Ni}$ & $\mathrm{Pb}$ & $\mathrm{Zn}$ \\
\hline$R f D_{\text {ing }}$ & $\mathrm{mg} \mathrm{kg}^{-1} \mathrm{day}^{-1}$ & $3.00 \mathrm{E}-04$ & $1.00 \mathrm{E}-03$ & $1.50 \mathrm{E}+00$ & $4.00 \mathrm{E}-02$ & $1.60 \mathrm{E}-04$ & $2.00 \mathrm{E}-02$ & $1.40 \mathrm{E}-04$ & $3.00 \mathrm{E}-01$ \\
\hline$R f D_{\text {derm }}$ & $\mathrm{mg} \mathrm{kg}^{-1} \mathrm{day}^{-1}$ & $3.00 \mathrm{E}-04$ & $2.50 \mathrm{E}-05$ & $1.95 \mathrm{E}-02$ & $4.00 \mathrm{E}-02$ & $1.60 \mathrm{E}-04$ & $8.00 \mathrm{E}-04$ & $1.40 \mathrm{E}-04$ & $3.00 \mathrm{E}-01$ \\
\hline$R f D_{\text {inh }}$ & $\mathrm{mg} \mathrm{kg}^{-1} \mathrm{day}^{-1}$ & $3.00 \mathrm{E}-04$ & $5.71 \mathrm{E}-05$ & $2.86 \mathrm{E}-05$ & - & $8.57 \mathrm{E}-05$ & $2.06 \mathrm{E}-02$ & - & $3.00 \mathrm{E}-01$ \\
\hline $\mathrm{SF}_{\text {ing }}$ & $\mathrm{mg} \mathrm{kg}^{-1} \mathrm{day}^{-1}$ & $1.50 \mathrm{E}+00$ & - & $5.01 \mathrm{E}-01$ & - & - & $1.70 \mathrm{E}+00$ & - & - \\
\hline $\mathrm{SF}_{\text {derm }}$ & $\mathrm{mg} \mathrm{kg}^{-1} \mathrm{day}^{-1}$ & $3.66 \mathrm{E}+00$ & - & $2.00 \mathrm{E}+01$ & - & - & $4.25 \mathrm{E}+01$ & - & - \\
\hline $\mathrm{SF}_{\text {inh }}$ & $\mathrm{mg} \mathrm{kg}^{-1} \mathrm{day}^{-1}$ & $1.51 \mathrm{E}+01$ & $6.30 \mathrm{E}+00$ & $4.20 \mathrm{E}+01$ & - & - & $9.01 \mathrm{E}-01$ & - & - \\
\hline
\end{tabular}


then it indicates an unacceptable CR. Table 3 displays the unit and value of SF.

\section{Positive Matrix Factorization (PMF)}

PMF, which is based on factor analysis, is an efficient source apportionment method [29]. In the PMF model, the concentration data matrices of samples are decomposed into contribution and profile matrices of a factor. According to the result of factorization, profile information was obtained, emission inventories were collected, and sources could be identified [30]. PMF was expressed as follows [29]:

$$
\mathrm{x}_{\mathrm{ij}}=\sum_{\mathrm{k}=1}^{\mathrm{p}} \mathrm{g}_{\mathrm{ik}} \mathrm{f}_{\mathrm{kj}}+\mathrm{e}_{\mathrm{ij}}
$$

... where $x_{i j}$ is the concentration of species $\mathrm{j}$ in sample $\mathrm{i}$, $p$ is the number of factors, $g_{i j}$ is the related contribution of factor $\mathrm{k}$ to sample $\mathrm{i}, \mathrm{f}_{\mathrm{kj}}$ is the concentration of species $\mathrm{j}$ in factor $\mathrm{k}$, and $\mathrm{e}_{\mathrm{ij}}$ pertains to the residuals.

The contributions and profiles of the factor are obtained by the PMF model through minimizing Q as follows [31]:

$$
\mathrm{Q}=\sum_{\mathrm{i}=1}^{\mathrm{n}} \sum_{\mathrm{j}=1}^{\mathrm{m}}\left(\frac{\mathrm{e}_{\mathrm{ij}}}{\mathrm{u}_{\mathrm{ij}}}\right)^{2}
$$

...where $\mathrm{u}_{\mathrm{ij}}$ represents uncertainty, which is evaluated as follows [32]:

$$
u_{i j}=\left\{\begin{array}{c}
\frac{5}{6} \times M^{2}, x_{i j} \leq M D L \\
\sqrt{\left(\sigma_{j} \times x_{i j}\right)^{2}+(M D L)^{2}}, x_{i j}>M D L
\end{array}\right.
$$

...where $\sigma_{j}$ is the relative standard deviation of the concentration of species $\mathrm{j}$.
EPA PMF 5.0 was used, and the maximum number of runs was set to 500. Initially, based on the signalto-noise ratio, the species were classified as "strong," "weak," or "bad." At run time, we can adjust it according to the results of the simulation. When the scaled residuals of all elements ranged from -3 to +3 , and differences between $\mathrm{Q}_{\text {true }}$ and $\mathrm{Q}_{\text {robust }}$ were extremely little, the simulation could be viewed as stable, and predicted concentrations of metals could be obtained. If the correlation between observed and predicted values are weak, the weight of the species should be reduced or removed from the model.

\section{Results and Discussion}

\section{General Characteristics of Metals in Agricultural Soil}

According to the mean concentrations of heavy metals, they integrally decrease in the following order $\mathrm{Zn}>\mathrm{Cr}>\mathrm{Ni}>\mathrm{Pb}>\mathrm{As}>\mathrm{Cu}>\mathrm{Cd}>\mathrm{Hg}$ with 120.85, 91.86, 56.01, 12.22, 9.71, 9.31, 1.03, and $0.03 \mathrm{mg} / \mathrm{kg}$, respectively. The background concentrations of heavy metals can be ordered as follows: $\mathrm{Zn}>\mathrm{Cr}>\mathrm{Ni}>\mathrm{Pb}>\mathrm{Cu}>\mathrm{As}>\mathrm{Cd}>\mathrm{Hg}$ with $59.80,57.90,23.80,20.30,19.80,8.80,0.11$, and 0.04 $\mathrm{mg} / \mathrm{kg}$, respectively (Table 4). The decreasing order of median values differs from that of the background value, which indicates that $\mathrm{As}$ and $\mathrm{Cu}$ are probably influenced by external factors. The maximum values of all heavy metals are greater than those of the background values in this area. Except for $\mathrm{Cu}, \mathrm{Hg}$, and $\mathrm{Pb}$, the mean concentrations of heavy metals surpassed their respective background values [16]. The mean concentration of $\mathrm{Cd}$ was nine times that of the

\begin{tabular}{|c|c|c|c|c|c|c|c|c|c|}
\hline & & As & $\mathrm{Cd}$ & $\mathrm{Cr}$ & $\mathrm{Cu}$ & $\mathrm{Hg}$ & $\mathrm{Ni}$ & $\mathrm{Pb}$ & $\mathrm{Zn}$ \\
\hline \multirow{6}{*}{$\begin{array}{l}\text { Fuxin, } \\
\text { China }\end{array}$} & Background [16] & 8.80 & 0.11 & 57.90 & 19.80 & 0.04 & 23.80 & 20.30 & 59.80 \\
\hline & Mean & 9.71 & 1.03 & 91.86 & 9.31 & 0.03 & 56.01 & 12.22 & 120.85 \\
\hline & Median & 10.18 & 0.26 & 77.85 & 8.00 & 0.03 & 52.00 & 4.60 & 98.90 \\
\hline & Min & 1.99 & 0.16 & 5.10 & 1.20 & 0.02 & 28.20 & 1.00 & 24.10 \\
\hline & Max & 11.20 & 10.20 & 278.00 & 37.20 & 0.06 & 138.30 & 92.10 & 433.20 \\
\hline & Variance & 0.18 & 1.50 & 0.68 & 0.66 & 0.30 & 0.27 & 1.22 & 0.54 \\
\hline \multirow{6}{*}{$\begin{array}{c}\text { Reference } \\
\text { areas }\end{array}$} & Hexi Corridor, China [36] & - & - & 97.51 & 35.20 & - & 47.42 & 5.54 & 75.34 \\
\hline & Zhejiang, China [18] & 29.55 & 1.24 & 76.19 & 31.77 & 0.54 & 39.78 & 182.67 & 96.80 \\
\hline & Hunan, China [37] & 21.05 & 0.85 & 74.96 & 38.85 & 0.25 & 26.83 & 56.06 & 147.28 \\
\hline & Taiyuan, China [38] & 10.70 & 0.25 & 74.10 & 32.11 & 0.09 & 29.74 & 27.87 & 90.76 \\
\hline & Beijing, China [35] & 7.99 & 0.20 & 58.15 & 26.78 & 0.13 & 21.22 & 22.64 & 78.03 \\
\hline & Singhbhum, India [39] & 29.70 & 0.34 & 149.60 & 218.00 & - & 94.20 & 47.00 & 210.60 \\
\hline
\end{tabular}
background value. This finding indicated that industrial

Table 4. Concentrations of eight heavy metals in agricultural soils of the study region and reference regions $(\mathrm{mg} / \mathrm{kg})$. 
activities such as mining have contributed to soil pollution [33].

Except for $\mathrm{Cd}$, the mean values of other heavy metals were lower than those of the screening values of soil pollution risk of agricultural land [34]. The concentrations of most metals in Fuxin, except for $\mathrm{Cu}$, $\mathrm{Hg}$, and $\mathrm{Pb}$, were higher than those in Beijing [35]. The concentrations of $\mathrm{Ni}, \mathrm{Pb}$, and $\mathrm{Zn}$ were higher than those in Hexi Corridor, China [36]. Compared with the economically developed provinces in southern China, the concentrations of most of the heavy metals in Fuxin were lower than those in Zhejiang and Hunan provinces, China $[18,37]$. In addition, the concentrations of $\mathrm{As}, \mathrm{Cu}$, $\mathrm{Hg}$, and $\mathrm{Pb}$ in Fuxin were lower than those in Taiyuan, China, whereas the opposite is true for other heavy metals [38]. Except for Cd, the concentrations of most metals in Fuxin were lower than those in Singhbhum, India [39].

For most heavy metals, the concentrations in the Haizhou and Xihe areas and south of Fumeng county were significantly higher than those of other areas (Fig. 2). Many large areas of mines are abandoned land near the urban area. Haizhou Terrace Coal Mine, which is the largest open pit coal mine in Asia, is located in Haizhou District, Fuxin city. The distance from the closest sampling point to the Haizhou Mine was approximately $1 \mathrm{~km}$ away, and the content of the heavy metals tends to decrease with the increase in distance. Mining industry activities caused the accumulation of heavy metals in soil. Furthermore, the accumulation and weathering of coal gangue, which is a solid waste produced by coal mining, was considered an important reason for the accumulation of heavy metals [40]. The spatial distribution of As concentration in agricultural soil is relatively uniform. Accumulative As in agricultural soil suggested that it was derived from the application of fertilizers and pesticides. The spatial distribution patterns of $\mathrm{Cd}$ and $\mathrm{Pb}$ have similar trends. Relatively high contents of $\mathrm{Cd}$ and $\mathrm{Pb}$ were detected in agricultural land in the Haizhou and Xihe areas. Historically, sewage irrigation was installed in this region. Long-term irrigation with industrial wastewater might have resulted in the accumulation of heavy metals in soil [41-42]. With respect to $\mathrm{Cd}$, high concentration
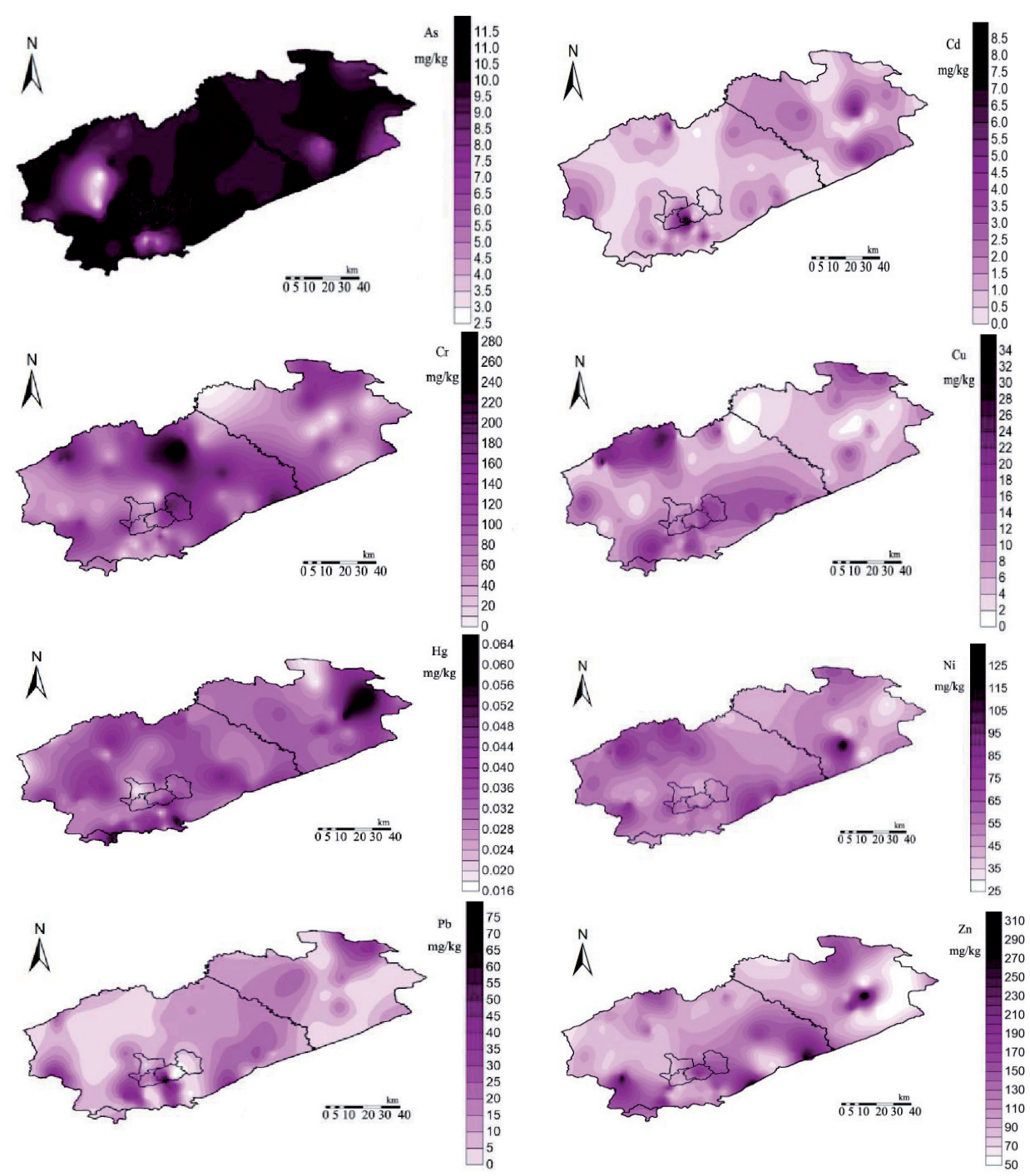

Fig. 2. Spatial distribution of the concentrations of eight heavy metals in Fuxin. 
areas pertain to the jurisdiction and central areas of Zhangwu County. The maximum concentration of $\mathrm{Cd}$ was as high as $10.20 \mathrm{mg} / \mathrm{kg}$, which is 34 times that of the screening value (soil environmental quality risk control standard for soil contamination of agricultural land in China) [34]. These study regions are characterized by high-intensity industrial activity and dense population, which can affect the spatial distribution of heavy metals $[13,27]$. The highest concentrations of $\mathrm{Cr}, \mathrm{Cu}$, and $\mathrm{Ni}$ were observed south and southwest of Fumeng County, and the trends of the spatial distribution of these heavy metals were roughly in line. This finding suggested that these metals might be derived from a common pollution source. The concentrations of $\mathrm{Ni}$ and $\mathrm{Zn}$ were higher in the south-central area compared with other areas of Zhangwu County. This observation indicated that the mining of gold deposits was the reason for the high concentrations of $\mathrm{Ni}$ and $\mathrm{Zn}$ in farmland near the mining area. High concentrations of $\mathrm{Hg}$ were mainly observed south of Fumeng Country and northeast of Zhangwu County. These areas might be related to the dominant local wind direction. The fine soil particles that adhere to heavy metals can be readily transported by wind [43]. The dominant wind directions in Fumeng and Zhangwu counties are northwest and southwest, respectively. Atmospheric pollutants could have migrated to the south of Fumeng and northeast of Zhangwu. The spatial distribution of the concentrations of eight heavy metals in the entire study region followed a similar trend.

\section{Pollution Levels and Ecological and Health Risks}

The results of $\mathrm{I}_{\text {geo }}$ indicate that none of the sampling sites were polluted by As, and the majority of the sampling sites were not contaminated by $\mathrm{Cu}, \mathrm{Hg}$, and $\mathrm{Pb}$ (Fig. 3a). The pollution level of $\mathrm{Cd}$ was higher than those of other metals, where their values of $I_{\text {geo }}$ are bigger than 1 in a large number of sampling points. This finding indicated moderate contamination. With regard to the potential ecological risks, the values of $E_{r}^{i}$ for many heavy metals were lower than 40 , which indicated low risk in all sampling sites (Fig. 3b). The values of $E_{r}{ }^{i}$ for $\mathrm{Hg}$ surpassed 40 in certain sites, whereas most of the sampling points displayed values lower than 40 , which indicated low risk. The $E_{r}^{i}$ for Cd surpassed 40 in many sites, but a few sites exceeded 80 , which indicated moderate risk. In this study area, the results for $\mathrm{I}_{\mathrm{geo}}$ were similar to $E_{r}^{i}$, and $\mathrm{Cd}$ displayed moderate contamination and risk, whereas other heavy metals showed low risk. The values of RI were lower than 150 in the majority of the study areas, which indicated low risk. However, the values of RI were higher than 300 in a number of sites, such as Haizhou and Xihe, which indicated considerable risk. In other words, the heavy metal pollution in Fuxin was relatively light. However, increased attention should be paid to $\mathrm{Cd}$ in special sites.

Only the CRs of $\mathrm{As}, \mathrm{Cr}$, and $\mathrm{Ni}$ (three exposure pathways) and $\mathrm{Cd}$ (only inhalation) were evaluated due to the lack of slope factors. Table 5 displays the noncarcinogenic and CRs to children and adults posed by heavy metals in soil through ingestion, dermal contact and inhalation. The total HIs for children and adults were $5.93 \times 10^{-1}$ and $6.45 \times 10^{-2}$, respectively. The non-CRs of children were bigger than those of adults by approximately nine times. The reason was that compared with adults, children have higher respiration rates per unit body weight, have more gastrointestinal absorption of certain toxic elements, and do more handto-mouth activities [44]. However, these values are lower than 1, which indicated that the non-CRs posed by heavy metals in this area is non-significant.

For adults, the main exposure pathway of the nonCRs was ingestion, with an $\mathrm{HI}$ value of $6.25 \times 10^{-2}$. The HI values through dermal contact and inhalation were only $1.29 \times 10^{-3}$ and $6.58 \times 10^{-4}$, respectively. The
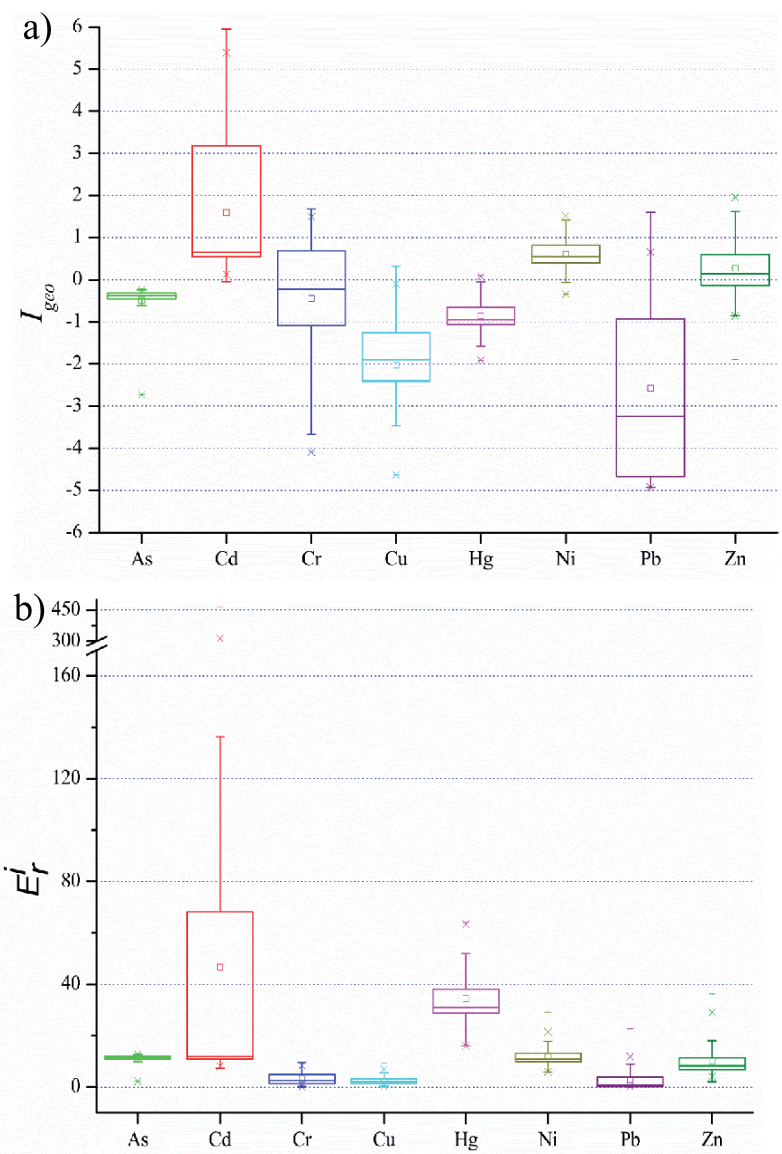

c)

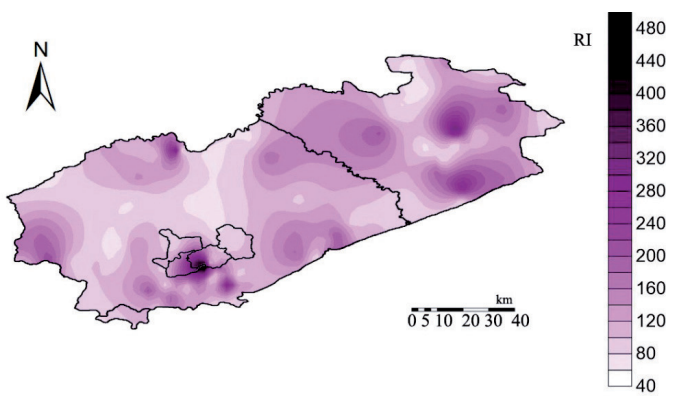

Fig. 3. Results of risk assessment: a) $I_{g e o}$; b) $E_{r}^{i}$; c) spatial distribution of RI. 
Table 5. Health risks to children and adults through different pathways and single heavy metal

\begin{tabular}{|c|c|c|c|c|}
\hline \multirow{2}{*}{} & \multicolumn{2}{|c|}{ Non-carcinogenic risks } & \multicolumn{2}{c|}{ Carcinogenic risks } \\
\cline { 2 - 5 } & Children & Adult & Children & Adult \\
\hline Ingestion & $5.84 \mathrm{E}-01$ & $6.25 \mathrm{E}-02$ & $1.71 \mathrm{E}-04$ & $7.32 \mathrm{E}-05$ \\
\hline Dermal & $8.46 \mathrm{E}-03$ & $1.29 \mathrm{E}-03$ & $1.31 \mathrm{E}-04$ & $7.97 \mathrm{E}-05$ \\
\hline Inhalation & $1.15 \mathrm{E}-03$ & $6.58 \mathrm{E}-04$ & $1.23 \mathrm{E}-07$ & $2.81 \mathrm{E}-07$ \\
\hline $\mathrm{As}$ & $4.15 \mathrm{E}-01$ & $4.45 \mathrm{E}-02$ & $1.71 \mathrm{E}-05$ & $7.52 \mathrm{E}-06$ \\
\hline $\mathrm{Cd}$ & $1.46 \mathrm{E}-02$ & $1.63 \mathrm{E}-03$ & $1.95 \mathrm{E}-10$ & $4.46 \mathrm{E}-10$ \\
\hline $\mathrm{Cr}$ & $2.08 \mathrm{E}-03$ & $7.57 \mathrm{E}-04$ & $1.07 \mathrm{E}-04$ & $5.63 \mathrm{E}-05$ \\
\hline $\mathrm{Cu}$ & $2.99 \mathrm{E}-03$ & $3.20 \mathrm{E}-04$ & - & - \\
\hline $\mathrm{Hg}$ & $2.83 \mathrm{E}-04$ & $3.08 \mathrm{E}-05$ & - & - \\
\hline $\mathrm{Ni}$ & $3.83 \mathrm{E}-02$ & $4.22 \mathrm{E}-03$ & $1.77 \mathrm{E}-04$ & $8.93 \mathrm{E}-05$ \\
\hline $\mathrm{Pb}$ & $1.15 \mathrm{E}-01$ & $1.24 \mathrm{E}-02$ & - & - \\
\hline $\mathrm{Zn}$ & $5.16 \mathrm{E}-03$ & $5.54 \mathrm{E}-04$ & - & - \\
\hline $\mathrm{Total}$ & $5.93 \mathrm{E}-01$ & $6.45 \mathrm{E}-02$ & $3.01 \mathrm{E}-04$ & $1.53 \mathrm{E}-04$ \\
\hline
\end{tabular}

main exposure contaminants of the non-CRs were As, $\mathrm{Pb}$ and $\mathrm{Ni}$, with contribution rates of $68.99 \%, 19.22 \%$, and $6.54 \%$, respectively. Adults have a similar trend with children in terms of the contributions of exposure pathways and heavy metals to non-CRs. Ingestion was the main exposure pathway, with an HI value of $5.84 \times 10^{-1}$ and contribution of $98.48 \%$. As, $\mathrm{Pb}$, and $\mathrm{Ni}$ were the main exposure contaminants for non-CRs with HI values of $4.15 \times 10^{-1}, 1.15 \times 10^{-1}$, and $3.83 \times 10^{-2}$, respectively. Their contributions were $69.98 \%, 19.39 \%$, and $6.46 \%$, respectively.

The total CRs for children and adults were $3.01 \times 10^{-4}$ and $1.53 \times 10^{-4}$, respectively. Similar to non-CRs, the CRs of children were larger than those of adults by approximately two times. They are all higher than $1 \times 10^{-4}$, which means that the CRs posed by heavy metals in this area were within unacceptable levels. For adults or children, the CRs of ingestion and dermal contact were similar and much higher than inhalation. For adults, the CRs of dermal contact were highest with a $\mathrm{CR}$ value of $7.97 \times 10^{-5}$. The $\mathrm{CR}$ values through ingestion and inhalation were $7.32 \times 10^{-5}$

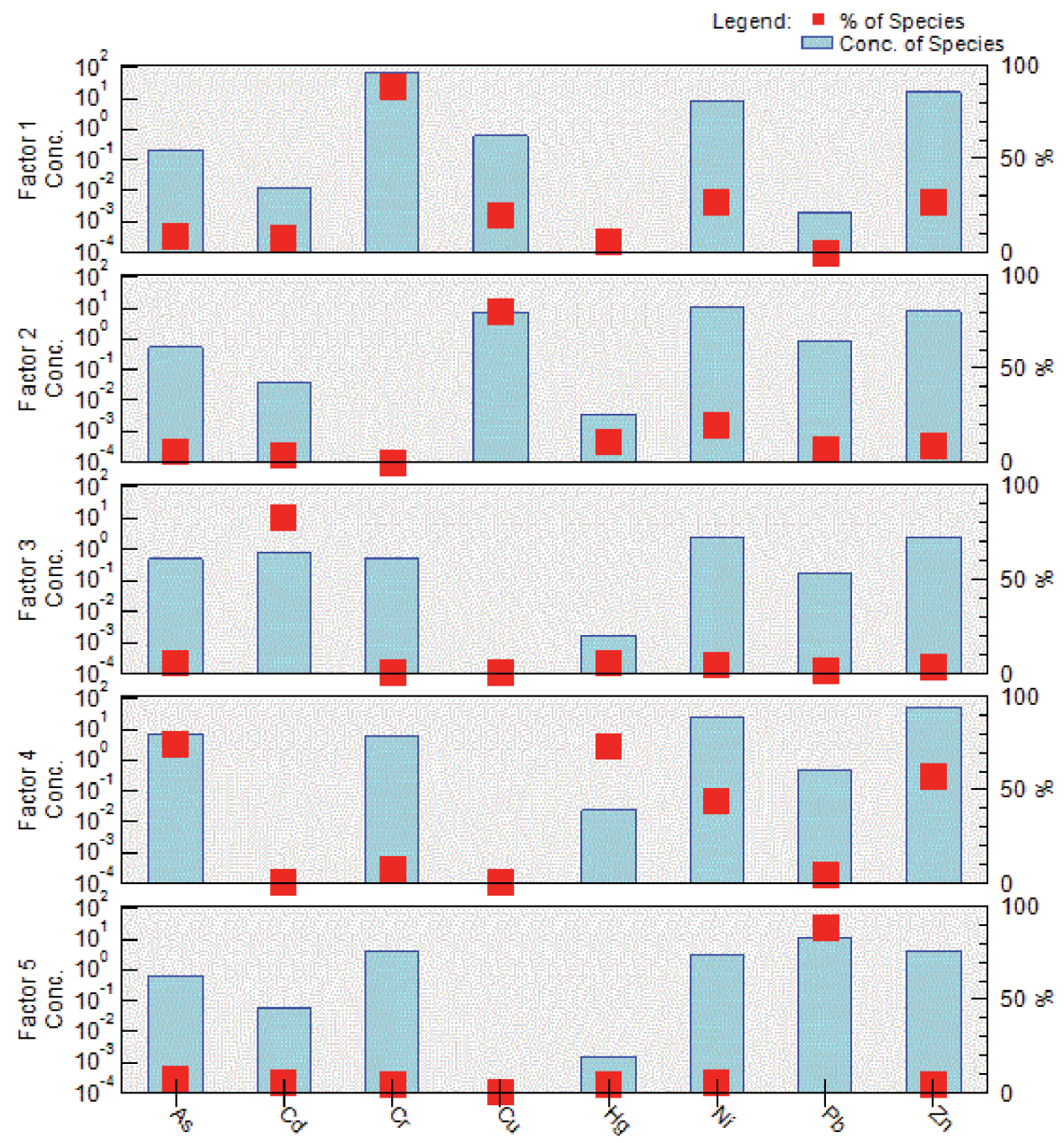

Fig. 4. Contributions of five main factors to eight heavy metals. 
and $2.81 \times 10^{-7}$, respectively. For children, the CRs of ingestion were highest with a CR value of $1.71 \times 10^{-4}$. The CR values through dermal contact and inhalation were $1.31 \times 10^{-4}$ and $1.23 \times 10^{-7}$, respectively. For adults or children, the main exposure contaminants of the $\mathrm{CRs}$ were $\mathrm{Ni}, \mathrm{Cr}$, and $\mathrm{As}$. The $\mathrm{CR}$ values of $\mathrm{Ni}, \mathrm{Cr}$, and As were $8.93 \times 10^{-5}, 5.63 \times 10^{-5}$ and $7.52 \times 10^{-6}$, respectively, and contributions were $58.37 \%, 36.80 \%$, and $4.92 \%$, respectively, for adults. The $\mathrm{CR}$ values of $\mathrm{Ni}, \mathrm{Cr}$, and As were $1.77 \times 10^{-4}, 1.07 \times 10^{-4}$, and $1.71 \times 10^{-5}$, respectively, and contributions were $58.80 \%$, $35.55 \%$, and $5.68 \%$, respectively, for children.

\section{Source Apportionment Based on PMF}

The results of PMF revealed that the signal-tonoise ratios of the eight heavy metals ranged from 2.5 to 4.3 , and the absolute scaled residuals are acceptable. These findings indicated that the model can well fit the eight heavy metals. The result of the model simulation revealed that five main factors affect the accumulation of the eight metals (Fig. 4).

Factor 1 contributed $88.01 \%$ to the concentration of $\mathrm{Cr}$. In agricultural soil, $\mathrm{Cr}$ pollution is mainly caused by human activities [45]. In northern China, farmers have to use sewage to irrigate and fertilize farmland due to water shortage and increasing fertilizer cost [46]. High concentrations of $\mathrm{Cr}$ indicate that sewage irrigation is the most likely anthropogenic source $[38,47]$. Therefore, factor 1 is derived from sewage irrigation.

Factor 2 accounted for $80.30 \%$ of the concentration of $\mathrm{Cu}$. To control gut flora and post-weaning scours, $\mathrm{Cu}$ is typically an additive present in livestock diets [4849]. Hence, a large amount of $\mathrm{Cu}$ exists in livestock and poultry dung - especially in pig manure [50]. With the application of livestock and poultry dung in local farming, $\mathrm{Cu}$ will be accumulated in agricultural soil. This accumulation is mainly related to livestock and poultry dung [46, 51-52]. Therefore, factor 2 represents livestock and poultry dung.

Factor 3 accounted for $82.45 \%$ of the concentration of $\mathrm{Cd}$. $\mathrm{Cd}$ is frequently regarded as a marker element for the application of chemical fertilizers - especially phosphate fertilizer [53]. Approximately $113 \mathrm{t}$ of $\mathrm{Cd}$ enter the agricultural soil in China every year through the application of chemical fertilizers [46]. Therefore, factor 3 represents chemical fertilizers.

Factor 4 contributed $73.55 \%, 73.01 \%, 56.49 \%$, and $43.13 \%$ to the concentrations of $\mathrm{As}, \mathrm{Hg}, \mathrm{Zn}$, and $\mathrm{Ni}$, respectively. High concentrations of As in soil might be related to industrial discharges [54-55]. Hg is typically applied in many medical apparatus and instruments, such as thermometers and sphygmomanometers. When these devices are broken or abandoned, $\mathrm{Hg}$ will be released to the environment. Medical waste is a potential source of $\mathrm{Hg}$ [56]. $\mathrm{Zn}$ and $\mathrm{Ni}$ come from industrial production, such as steel production, metal processing, and so on [57-58]. Briefly, factor 4 pertains to industrial sources.

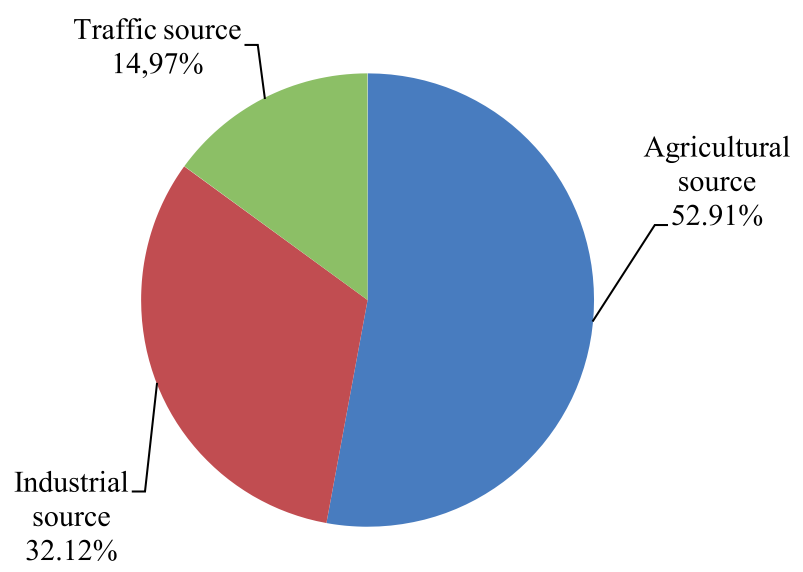

Fig. 5. Contributions of different sources to heavy metals pollution in Fuxin.

Factor 5 accounts for $87.84 \%$ of the total concentration of $\mathrm{Pb}$. Factors such as fuel combustion and catalyst application have led to $\mathrm{Pb}$ being considered as the main sign of traffic emission source [59-60]. Brake pad wear also accelerated the accumulation of $\mathrm{Pb}$ in soil [61]. Although the production and use of leaded gasoline has been prohibited since 2000, the concentration of $\mathrm{Pb}$ in soil continues to increase [58]. Hence, factor 5 represents a traffic source.

Factors 1, 2, and 3 are considered agricultural sources because sewage irrigation and the application of livestock manure and chemical fertilizers are agricultural activities. Fig. 5 depicts the contribution of different sources to heavy metal contamination in agricultural soil in Fuxin, China. Agricultural source contributed half to the concentrations of heavy metals. The contributions of industrial and traffic sources were $32.12 \%$ and $14.97 \%$, respectively. Agricultural activities remain the main source of heavy metal pollution in agricultural soil.

\section{Conclusions}

Except for $\mathrm{Cu}, \mathrm{Hg}$, and $\mathrm{Pb}$, the mean concentrations of other heavy metals surpassed their respective background values. The mean concentration of $\mathrm{Cd}$ was nine times that of the background value. And only the mean concentration of $\mathrm{Cd}$ was higher than the Chinese screening values of soil pollution risk for agricultural land. For the majority of the heavy metals, the concentrations in Haizhou and Xihe and southern Fumeng County were significantly higher than those of other areas. $\mathrm{I}_{\text {geo }}$ indicated that the levels of heavy metal pollution ranged from no pollution $(\mathrm{As}, \mathrm{Cu}, \mathrm{Hg}$, and $\mathrm{Pb})$ to moderate contamination $(\mathrm{Cd}) . E_{r}^{i}$ revealed that most heavy metals posed a low risk in all sampling points, whereas $\mathrm{Cd}$ posed moderate risk in many sites. RI showed that most of the study areas were low risk, whereas some sites, such as Haizhou and Xihe, were considerable risk. The non-CRs caused by heavy 
metals in these areas were small-beer, but the CRs were unacceptable. $\mathrm{Ni}, \mathrm{Cr}$, and $\mathrm{As}$ were the main carcinogenic pollutants, through ingestion and dermal contact as the major exposure pathways. The results of PMF revealed that agricultural activity was the major pollution source, which contributed half to the concentration of heavy metals. Industrial and traffic sources contributed $32.12 \%$ and $14.97 \%$, respectively.

\section{Acknowledgements}

This research was supported by the National Natural Science Foundation of China (Nos. 41501548 and 41807384), the general project for scientific research of Liaoning Provincial Education Department (LJ2019JL029), the Natural Science Foundation of Liaoning Province (No. 20170520384), and a China Postdoctoral Science Foundation-funded project (No. 2018M630304).

\section{Conflict of Interest}

The authors declare no conflict of interest.

\section{References}

1. ZHOU Q.X., SONG Y.F. Contaminated Soil Remediation: Principles and Methods (in Chinese). Science Press, Beijing, China. 2004.

2. MAZUREK R., KOWALSKA J., GĄSIOREK M., ZADROŻNY P., JÓZEFOWSKA A., ZALESKI T. Assessment of heavy metals contamination in surface layers of Roztocze National Park forest soils (SE Poland) by indices of pollution. Chemosphere 168, 839, 2016.

3. GĄSIOREK M., KOWALSKA J., MAZUREK R., PAJĄK M. Comprehensive assessment of heavy metal pollution in topsoil of historical urban park on an example of the Planty Park in Krakow (Poland). Chemosphere 179, 148, 2017.

4. WANG Y.C., AO L., LEI B., ZHANG S. Assessment of heavy metal contamination from sediment and soil in the riparian zone China's Three Gorges Reservoir. Polish Journal of Environmental Studies 24 (5), 2253, 2015.

5. XIAO Q., ZONG Y.T., LU S.G. Assessment of heavy metal pollution and human health risk in urban soils of steel industrial city (Anshan), Liaoning, Northeast China. Ecotoxicology \& Environmental Safety 120, 377, 2015.

6. PAN L.B., MA J., WANG X.L., HOU H. Heavy metals in soils from a typical county in Shanxi Province, China: levels, sources and spatial distribution. Chemosphere 148, 248, 2016.

7. WANG, G., ZHANG S., XIAO L., ZHONG Q., LI L.,XU G. Heavy metals in soils from a typical industrial area in Sichuan, China: spatial distribution, source identification, and ecological risk assessment. Environmental Science \& Pollution Research 24 (1), 1, 2017.

8. VAROL M. Assessment of heavy metal contamination in sediments of the tigris river (Turkey) using pollution indices and multivariate statistical techniques. Journal of Hazardous Materials 195 (1), 355, 2011.
9. MORINA A., MORINA F., DJIKANOVIĆ V., SPASIĆ S., KRPO-ĆETKOVIĆ, J., KOSTIĆ, B., LENHARDT, $\mathrm{M}$. Common barbel (Barbus barbus) as a bioindicator of surface river sediment pollution with $\mathrm{Cu}$ and $\mathrm{Zn}$ in three rivers of the Danube River Basin in Serbia. Environmental Science \& Pollution Research 23, 6723, 2015.

10. WCISŁO E., BRONDER J., BUBAK A., RODRÍGUEZVALDÉS E., GALLEGO J.L. Human health risk assessment in restoring safe and productive use of abandoned contaminated sites. Environment International 94, 436, 2016

11. ZHANG H., WU C.Q., GONG J.P., YUAN X.Y., WANG Q., PEI W.M., LONG T., QIU J., ZHANG H.P. Assessment of Heavy Metal Contamination in Roadside Soils Along the Shenyang-Dalian Highway in Liaoning Province, China. Polish Journal of Environmental Studies 26 (4), 1539, 2017.

12. HAMAD S.H., SCHAUER J.J., SHAFER M.M., AL-RHEEM E.A., SKAAR P.S., HEO J. Risk assessment of total and bioavailable potentially toxic elements (PTEs) in urban soils of Baghdad-Iraq. Science of the Total Environment 494-495, 39, 2014.

13. AMINIYAN M.M., BAALOUSHA M., MOUSAVI R., AMINIYAN F.M., HOSSEINI H., HEYDARIYAN A The ecological risk, source identification, and pollution assessment of heavy metals in road dust: a case study in Rafsanjan, SE Iran. Environmental Science \& Pollution Research 25 (14), 13382, 2018.

14. MEN C., LIU R., XU F., WANG Q., GUO L., SHEN, Z. Pollution characteristics, risk assessment, and source apportionment of heavy metals in road dust in Beijing, China. Science of the Total Environment 612, 138, 2018.

15. PATHAK A.K., KUMAR R., KUMAR P., YADAV S. Sources apportionment and spatio-temporal changes in metal pollution in surface and subsurface soils of a mixed type industrial area in India. Journal of Geochemical Exploration 159, 169, 2015.

16. WU W., WU P., YANG F., SUN D.L., ZHANG D.X., ZHOU Y.K. Assessment of heavy metal pollution and human health risks in urban soils around an electronics manufacturing facility. Science of the Total Environment 630, 53, 2018.

17. ZHUANG P., MCBRIDE M.B., XIA H.P., LI N.Y., LI Z. Health risk from heavy metals via consumption of food crops in the vicinity of Dabaoshan mine, South China. Science of the Total Environment 407 (5), 1551, 2009.

18. HUANG Y., CHEN Q., DENG M., JAPENGA J., LI T., YANG X. Heavy metal pollution and health risk assessment of agricultural soils in a typical peri-urban area in southeast China. Journal of Environmental Management 207, 159, 2018.

19. CSC (China State Council). Chinese gov't vows to curb soil pollution. Available online: http://www.china.org.cn/ environment/2012-10/31/content_26964743.htm. (accessed on 31, October, 2012.

20. ZAHRA A., HASHMI M.Z., MALIK R.N., AHMED Z. Enrichment and geo-accumulation of heavy metals and risk assessment of sediments of the Kurang Nallah-feeding tributary of the Rawal Lake Reservoir, Pakistan. Science of the Total Environment 470-471, 925, 2014.

21. EQANI S.A.M.A., KANWAL A., BHOWMIK A.K., SOHAIL M., ULLAH R., ALI S.M., ALAMDAR A., ALI N., FASOLA M., SHEN H. Spatial distribution of dust-bound trace elements in Pakistan and their implications for human exposure. Environmental Pollution 213, 213, 2016. 
22. CHEN H.Y., TENG Y.G., LU S.J., WANG Y.Y., WANG J.S. Contamination features and health risk of soil heavy metals in China. Science of the Total Environment 512513, 143, 2015.

23. MULLER G. Index of geoaccumulation in sediments of the Rhine River. GeoJournal 2,108, 1969.

24. HAN L., GAO B., WEI X., XU D., GAO L. Spatial distribution, health risk assessment, and isotopic composition of lead contamination of street dusts in different functional areas of Beijing, China. Environmental Science \& Pollution Research 23, 3247, 2016.

25. US EPA. National Center for Environmental Assessment, Washington DC, Exposure Analysis and Risk Characterization Group, Moya, J. Exposure Factors Handbook, 2002.

26. LI H., QIAN X., HU W., WANG Y., GAO H. Chemical speciation and human health risk of trace metals in urban street dusts from a metropolitan city, Nanjing, SE China. Science of the Total Environment 456-457, 212, 2013.

27. MA W., TAI L., QIAO Z., ZHONG L., WANG Z., FU $\mathrm{K}$. Contamination source apportionment and health risk assessment of heavy metals in soil around municipal solid waste incinerator: a case study in North China. Science of the Total Environment 631-632, 348, 2018.

28. DEHGHANI S., MOORE F., KESHAVARZI B., HALE B.A. Health risk implications of potentially toxic metals in street dust and surface soil of Tehran, Iran. Ecotoxicology and Environmental Safety 136, 92, 2017.

29. YU W., LIU R., XU F., MEN C., SHEN Z. Identifications and seasonal variations of sources of polycyclic aromatic hydrocarbons (PAHs) in the Yangtze River Estuary, China. Marine Pollution Bulletin 104, 347, 2016.

30. YU W., LIU R., WANG J., XU F., SHEN Z. Source apportionment of PAHs in surface sediments using positive matrix factorization combined with GIS for the estuarine area of the Yangtze River, China. Chemosphere 134, 263, 2015.

31. TIAN Y., SHI G., HAN S., ZHANG Y., FENG Y., LIU G., GAO L., WU J., ZHU T. Vertical characteristics of levels and potential sources of water-soluble ions in PM10 in a Chinese megacity. Science of the Total Environment 447, $1,2013$.

32. CHEN H., TENG Y., LI J., WU J., WANG J. Source apportionment of trace metals in river sediments: a comparison of three methods. Environmental Pollution 211, 28, 2016.

33. JI C.K., NEJAD Z.D., JUNG M.C. Arsenic and heavy metals in paddy soil and polished rice contaminated by mining activities in Korea. Catena 148, 92, 2017.

34. CEPA. Soil environmental quality Risk control standard for soil contamination of agricultural land Environmental Quality Standard for Soils. GB15618-2018. Ministry of Ecology and Environment of the People's Republic of China, 2018.

35. ZOU J.M., DAI W., GONG S.X., MA Z.Y. Analysis of spatial variations and sources of heavy metals in farmland soil of Beijing suburbs. PLOS ONE 10 (2), e0118082, 2015.

36. GUAN Q., WANG F., XU C., PAN N., LIN J., ZHAO R., YANG Y., LUO H. Source apportionment of heavy metals in agricultural soil based on PMF: A case study in Hexi Corridor, northwest China. Chemosphere 193, 189, 2018.

37. LI X., ZHAO Z., YUAN Y., WANG W., LI X. Heavy metal accumulation and its spatial distribution in agricultural soils: evidence from Hunan province, China. RSC Advances 8 (19), 10665, 2018.
38. LIU Y., WANG H.F., LI X.T., LI J.C. Heavy Metal Contamination of Agricultural Soils in Taiyuan, China. Pedosphere 25 (6), 901, 2015.

39. GIRI S., SINGH A.K., MAHATO M.K. Metal contamination of agricultural soils in the copper mining areas of Singhbhum shear zone in India. Journal of Earth System Science 126 (4), 49, 2017.

40. DANG Z., LIU C., HAIGH M.J. Mobility of heavy metals associated with the natural weathering of coal mine spoils. Environmental Pollution 118 (3), 419, 2002.

41. LI P., WANG X., ALLINSON G., LI,X., XIONG X. Risk assessment of heavy metals in soil previously irrigated with industrial wastewater in Shenyang, China. Journal of Hazardous Materials 161 (1), 516, 2009.

42. KLAY S., CHAREF A., AYED L., HOUMAN B., REZGUI F. Effect of irrigation with treated wastewater on geochemical properties (saltiness, c, n and heavy metals) of isohumic soils (zaouit sousse perimeter, oriental tunisia). Desalination 253 (1), 180, 2010.

43. ZHAO H., LI X., WANG X., TIAN D. Grain size distribution of road-deposited sediment and its contribution to heavy metal pollution in urban runoff in Beijing, China. Journal of Hazardous Materials 183 (1), 203, 2010.

44. LI Z., MA Z., VAN DER KUIJP T.J., YUAN Z., HUANG L. A review of soil heavy metal pollution from mines in China: pollution and health risk assessment. Science of the Total Environment 468, 843, 2014.

45. ZHANG X.Y., ZHONG T.Y, LIU L., ZHANG X.M., CHENG, M., LI, X.H., JIN, J.X. Chromium occurrences in arable soil and its influence on food production in China. Environmental Earth Sciences 75 (3), 257, 2016.

46. LUO L., MA Y., ZHANG S., WEI D., ZHU Y.G. An inventory of trace element inputs to agricultural soils in China. Journal of Environmental Management 90 (8), 2524, 2009.

47. LI J.L., MING H., WEI H., GU Y.F. Analysis and assessment on heavy metal sources in the coastal soils developed from alluvial deposits using multivariate statistical methods. Journal of Hazardous Materials 164 (2-3), 976, 2009.

48. ROSEN G.D., ROBERTS P.A. Comprehensive survey of the response of growing pigs to supplementary copper in feed. Field Investigations and Nutrition Service Ltd, London, 1996.

49. HOLM A.E. Coli associated diarrhoea in weaner pigs: zinc oxide added to the feed as a preventive measure. International Pig Veterinary Society, Congress, July 1-5, Lausanne, Switzerland, 1990.

50. XIONG X.O., LI Y.X., LI W., LIN C.Y., HAN W., YANG M. Copper content in animal manures and potential risk of soil copper pollution with animal manure use in agriculture. Resources Conservation and Recycling 54 (11), 985, 2010

51. NICHOLSON F.A., SMITH S.R., ALLOWAY B.J., CARLTON-SMITH C., CHAMBERS B.J. An inventory of heavy metal input to agricultural soil in England and Wales. Science of the Total Environment 546 (1-3), 205, 2003.

52. LIANG J., FENG C.T., ZENG G.M., GAO X., ZHONG M.Z., LI X.D., LI X., HE X.Y., FANG Y.L. Spatial distribution and source identification of heavy metals in surface soils in a typical coal mine city, Lianyuan, China. Environmental Pollution 225, 681, 2017.

53. SUN C.Y., LIU J.S., WANG Y., SUN L.Q., YU H.W. Multivariate and geostatistical analyses of the spatial distribution and sources of heavy metals in agricultural 
soil in Dehui, Northeast China. Chemosphere 92, 517, 2013.

54. CHARLESWORTH S., EVERETT M., MCCARTHY R., ORDONEZ A., DE MIGUEL E. A comparative study of heavy metal concentration and distribution in deposited street dusts in a large and a small urban area: Birmingham and Coventry, West Midlands, UK. Environment International 29, 563, 2003.

55. ZHAO L., XU Y., HOU H., SHANGGUAN Y., LI F. Source identification and health risk assessment of metals in urban soils around the Tanggu chemical industrial district, Tianjin, China. Science of the Total Environment 468, 654, 2014

56. LI Y., YU Y., YANG Z., SHEN Z., WANG X., CAI Y. A comparison of metal distribution in surface dust and soil among super city, town, and rural area. Environmental Science \& Pollution Research 23 (8), 7849, 2016.

57. QU M.K., LI W.D., ZHANG C.R., WANG S.Q., YANG Y., HE L.Y. Source Apportionment of Heavy Metals in Soils
Using Multivariate Statistics and Geostatistics. Pedosphere 23 (4), 437, 2013.

58. CHEN T., CHANG Q.R., LIU J., CLEVERS J.G.P.W., KOOISTRA L. Identification of soil heavy metal sources and improvement in spatial mapping based on soil spectral information: A case study in northwest China. Science of the Total Environment 565, 155, 2016.

59. HJORTENKRANS D., BO B., HÄGGERUD A. New metal emission patterns in road traffic environments. Environmental Monitoring and Assessment 117 (1-3), 85, 2006.

60. ARDITSOGLOU A., SAMARA C. Levels of total suspended particulate matter and major trace elements in Kosovo: a source identification and apportionment study. Chemosphere 59 (5), 669, 2005.

61. SMICHOWSKI P., GÓMEZ D., FRAZZOLI C., CAROLI S. Traffic-related elements in Arborne Particulate Matter. Applied Spectroscopy Reviews 43, 23, 2007. 